\title{
Serum biochemical profile of Pêga breed donkeys in the state of Minas Gerais ${ }^{1}$
}

\author{
João B.F. Santos ${ }^{2 *}$, Maurício M. Franco ${ }^{3}$, Robson C. Antunes ${ }^{3}$, \\ Ednaldo C. Guimarães ${ }^{4}$ and Antonio V. Mundim ${ }^{2}$
}

\begin{abstract}
Santos J.B.F., Franco M.M., Antunes R.C., Guimarães E.C. \& Mundim A.V. 2018. Serum biochemical profile of Pêga breed donkeys in the state of Minas Gerais. Pesquisa Veterinária Brasileira 38(6):1225-1231. Faculdade de Medicina Veterinária, Universidade Federal de Uberlândia, Avenida Pará 1720, bloco 2T, Uberlândia, MG 38400-902, Brazil. E-mail: joaos@ufu.br

For the evaluation of serum biochemical parameters of Pêga breed donkeys (Equus asinus), for the different age groups and sex, blood samples of 123 animals were analyzed, of 29 males aged from 8 days to 10 years and of 94 females (15 lactating) aged from 2 days to 12 years, from two farms in the central-southern Minas Gerais, Brazil. The donkeys were divided by age into 5 groups: Group 1 ( $\leq 6$ months), Group 2 (7-12 months), Group 3 (13-48 months), Group 4 (49-72 months), and Group 5 ( $\geq 73$ months). According to the sex, they were divided into two groups, males and females. Serum biochemical elements: total protein, albumin, globulin, the A:G ratio, cholesterol, triglycerides, uric acid, creatinine, urea, phosphorus, calcium, Ca:P ratio, magnesium, alanine aminotransferase (ALT), aspartate aminotransferase (AST), alkaline phosphatase (ALP), gamma glutamyl transferase (GGT) and creatine kinase (CK), were evaluated in all animals. No significant differences were found for globulins, uric acid, urea and A:G ratio between age groups. Group 4 showed the highest values for total protein when compared with animals in Group 1 and 2. In Goup 2, the donkeys showed albumin levels lower than Group 3 and 4. Group 1 they had cholesterol levels higher than those in Group 2 and 4, and similar of the other groups. Higher phosphorus serum concentration was observed in Group 1. Calcium was significantly lower in Group 2. The Ca:P ratio was higher for Group 5. The magnesium values were significantly higher in donkeys older than 49 months (Group 4 and 5). The value of AST was lower for group 1. The ALP enzyme was significantly higher in younger animals up to 12 months, followed by gradual decrease with advancing age. The values of GGT were higher in donkeys up to 6 months, followed by decreasing values for subsequent groups. No differences were found between genders for albumin, cholesterol, creatinine, urea, uric acid, Ca:P ratio, magnesium, ALT, AST, and alkaline phosphatase. Females had higher values for total protein, globulin and triglycerides. Males showed higher values for A:G ratio, phosphorus, calcium and CK. The results showed that age and sex can influence serum biochemical values of Pêga breed donkeys.
\end{abstract}

INDEX TERMS: Donkey, Equus asinus, Pêga breed, serum biochemical profile, biochemistry.

\footnotetext{
${ }^{1}$ Received on June 28, 2017.

Accepted for publication on July 5, 2017.

${ }^{2}$ Faculdade de Medicina Veterinária, Universidade Federal de Uberlândia (UFU), Avenida Pará 1720, bloco 2T, Uberlândia, MG 38400-902, Brazil. *Corresponding author: joaos@ufu.br

${ }^{3}$ Laboratório de Produção Animal, Embrapa Recursos Genéticos e Biotecnologia, Avenida W5 norte, Cx. Postal 02372, Parque Estação Biológica, Brasília, DF 70770-900, Brazil.

${ }^{4}$ Faculdade de Matemática, Universidade Federal de Uberlândia (UFU), Av. João Naves de Ávila 2121, bloco 1F, Uberlândia, MG 38408-100, Brazil.
}

RESUMO.- [Perfil bioquímico sérico de jumentos da raça Pêga no estado de Minas Gerais.] Para a avaliação dos parâmetros bioquímicos séricos de jumentos (Equus asinus) da raça Pêga, quanto às diferentes faixas etárias e sexo, foram analisadas amostras sanguíneas de 123 animais, sendo 29 machos com idades de 8 dias a 10 anos e 94 fêmeas (15 lactantes) de 2 dias a 12 anos, de dois criatórios na região centro-sul do estado de Minas Gerais. Os animais foram divididos em 5 grupos de acordo com as idades: 
Grupo 1 ( $\leq 6$ meses); Grupo 2 (7-12 meses); Grupo 3 (13-48 meses); Grupo 4 (49-72 meses) e Grupo 5 ( $\geq 73$ meses). De acordo com o sexo, foram divididos em dois grupos, machos e fêmeas. Para todos os animais foram realizadas as análises de proteínas totais, albumina, globulinas, relação A:G, colesterol, triglicérides, ácido úrico, creatinina, ureia, fósforo, cálcio, relação Ca:P, magnésio, alanina aminotransferase (ALT), aspartato aminotransferase (AST), fosfatase alcalina (FAL), gama glutamiltransferase (GGT) e creatina quinase (CK). Não foram encontradas diferenças significativas para os elementos globulinas, ácido úrico, ureia e relação A:G entre as faixas etárias. O Grupo 4 apresentou os maiores valores para proteínas totais quando comparados aos animais dos grupos 1 e 2. Os animais do Grupo 2 mostraram valores de albumina inferiores aos Grupos 3 e 4 . Os animais do Grupo 1 apresentaram valores de colesterol superiores aos do Grupo 2 e 4, e semelhante aos demais grupos. Maior concentração sérica de fósforo foi observada nos animais do grupo 1.0 cálcio apresentou valor significativamente menor no Grupo 2. A relação Ca:P foi maior para o grupo 5. Os valores do magnésio foram estatisticamente superiores nos animais com idade superior a 49 meses (Grupos 4 e 5). O valor da AST foi menor para o Grupo 1.As enzimas FAL apresentaram valor significativamente maior nos animais mais jovens até 12 meses, seguida de redução gradual com o avançar da idade. Os valores da GGT foi maior nos jumentos com até seis meses de idade, seguido de valores decrescentes para os grupos subsequentes. Não foram encontradas diferenças entre os sexos para albumina, colesterol, creatinina, ureia, ácido úrico, relação Ca:P, magnésio, ALT, AST e fosfatase alcalina. As fêmeas tiveram valores maiores para proteínas totais, globulinas e triglicérides. Os machos mostraram maiores valores para relação $A: G$, fósforo, cálcio e CK. Pelos resultados nota-se que a idade e o sexo podem influenciar nos valores bioquímicos séricos dos jumentos da raça Pêga.

TERMOS DE INDEXAÇÃO: Equus asinus, jumento Pêga, bioquímica sérica.

\section{INTRODUCTION}

The Brazilian asinine herd is the seventh largest in the world, consisting of 902,716 donkeys (IBGE 2014). Donkeys (Equus asinus) are important for the production of mules, used on farms in various types of work, in sports and leisure. Since the beginning of colonization, these animals have played an important role in the development of rural areas, especially in the internalization of Brazilian civilization. The donkey is still an important animal for carrying loads, for riding, for the production of mules as a companion animal and producer of meat and milk for human consumption (Jordana et al. 1998, Araújo 2010, Sgorbini et al. 2013, Laus et al. 2015), as well as being used in developing countries for pulling farm implements in subsistence crops (Starkey \& Starkey 2000, Kugler et al. 2008). Carroccio et al. (2000), claim that the donkey's milk is used by children allergic to cow's milk.

The use of the biochemical profile is important in equine medicine to determine the health state of animals (Duncan et al.1994, Etana et al. 2011, Muñoz et al. 2012). Tasker (1978), in studies carried out on donkeys, already signaled the need for the determination of laboratory testing reference values for donkeys, however, in subsequent decades, little research has been conducted on this species. This reinforces the need for more studies on these animals (Al-Busadah \& Homeida 2005). In the routine of many veterinarians, serum biochemical values found in horses are used for comparison with donkeys. This comparison is erroneous, given the differences that exist between these species (Zinkl et al. 1990, Trachsel et al. 2005, Veronesi et al. 2014). The objective of this study was to find the variations of serum biochemical constituents in donkeys of the Pêga breed in good health, by gender and in different age groups to contribute to the serum biochemical pattern of this breed.

\section{MATERIALS AND METHODS}

Blood samples of 123 donkeys of the Pêga breed (Equus asinus) were used, 29 males aged from between 8 days to 10 years and 94 females (15 lactants) aged from between 2 days to 12 years, coming from two farms in the Central South region of Minas Gerais, and the collections were taken in the period from March 2014 to February 2015. All the animals were intended only for breeding and bred in semi-extensive conditions in Tifton grass paddocks, receiving hay supplementation of Tifton grass, commercial concentrated feed and mineral salt available in the paddocks and in stalls where the breeding animals are kept. The food management, sanitation, reproductive and rearing conditions on the two properties were similar. During the collection of blood samples the animals were evaluated clinically and had good health and good body condition. The samples were collected in the environment where the animals were, with the halter as the only restraint used. None of the animals was fasting. Blood collections were made in the afternoon, by venipuncture of the jugular with cleansing of site with cotton soaked in iodized alcohol $2 \%$ and dried with paper towels. The animals were divided by age into 5 groups: Group 1, up to 6 months (8 females and 7 males); Group 2,7 to 12 months (20 females and 8 males); Group 3, 13-48 months (23 females and 8 males); Group 4, 49 to 72 months ( 16 females and 3 males); Group $5>73$ months (27 females and 3 males). According to the sex, they were divided into two groups, males and females.

Disposable needles were used for vacuum blood collection $38 \times 1.25 \mathrm{~mm}$ (VACUETTE ${ }^{\circledR}$ ) coupled to the vacutainer adapter $0.70 \times 25 \mathrm{~mm}$ (VACUETTE ${ }^{\circledR}$ ) for the animals with thicker skin. For the finer skin and less muscular animals gauge $25 \times 0,8 \mathrm{~mm}$ (VACUPLAST ${ }^{\circledR}$ ) needles also with adapter were used to. From each animal $8 \mathrm{~mL}$ of blood were collected in disposable sterile tubes $\left(\right.$ VACUETTE $\left.^{\circledR}\right)$ of $8 \mathrm{~mL}$ with clot activator. After collection the samples were packed in isothermal box with recyclable ice until the time of centrifugation, performed 2 hours after collection. Blood samples were centrifuged for 5 minutes at $720 \mathrm{~g}$, the obtained serum was aliquoted into microtubes cryogenic Plasma $1.8 \mathrm{~mL}\left(\right.$ GETC $\left.1.85^{\circledR}\right)$, frozen at $-20^{\circ} \mathrm{C}$ and transported in insulated boxes to the Clinical Laboratory of the Veterinary Hospital of the Federal University of Uberlândia.

The serum biochemical analyzes were performed at the Clinical Laboratory of the Veterinary Hospital of UFU, in multichannel automatic analyzer (CHEMWELL ${ }^{\circledR}$ - Awareness Technology Inc., Palm City, USA) using commercial kits from Labtest Diagnóstica ${ }^{\circledR}$. The analyzer was previously calibrated with calibrates $\mathrm{H}$; and measured with universal control serum QUALITROL H, produced by Labtest Diagnóstica ${ }^{\circledR}$. The Biochemical parameters are listed in Table 1. The normality test of the residuos of the ANOVA mathematical model was applied and verified non-normal distribution. Therfore the Kruskal-Wallis test was used to check the differences of the elements between the age groups and the Man-Whitney test for the sexes, both with $5 \%$ significance level. 
RESULTS

The results of the statistical analysis of proteins, metabolites, minerals and evaluated serum enzymes, according to age groups are shown in Table 2 and 3. Comparing the protein

Table 1. Evaluated serum biochemical parameters with their methodologies used for analysis

\begin{tabular}{ll}
\hline \multicolumn{1}{c}{ Biochemical parameters } & \multicolumn{1}{c}{ Methodology } \\
\hline Total proteins (T. prot.) & Biuret method \\
Albumin (Alb.) & Bromocresol green method \\
Globulins (Glob.) & Tot. prot./almbumin-calculation \\
A:G ratio & Albumin/globulin-calculation \\
Cholesterol (Chol.) & Enzimatic-Trinder method \\
Tryglicerides (Trigl.) & Enzimatic-Trinder method \\
Uric acid & Enzimatic-Trinder method \\
Creatinine (Creat.) & Jaffe-modified method \\
Urea & Kinetic enzymatic method-UV \\
Phosphorus (P) & Kinetic method-UV \\
Calcium (Ca) & Cresolfitalein complexona - CPC \\
Ca:P ratio & Calcium/phosphorus-calculation \\
Magnesium (Mg) & Magon sulfonate method \\
Alanine aminotransferase (ALT) & Kinetic method UV-IFCC \\
Aspartate aminotransferase (AST) & Kinetic method UV-IFCC \\
Alkaline phosphatase (FAL) & Kinetic method IFCC \\
Gamma glutamiltransferase (GGT) & Modified Szasz method \\
Creatine kinase (CK) & Kinetic method UV-IFCC \\
\hline UV = ultraviolet, IFCC = International Federation of Clinical Chemistry.
\end{tabular}

and serum metabolites values between age groups (Table 2) there was no significant difference as to globulins, uric acid, urea and the $A: G$ association. The animals belonging to Group 4 showed higher total proteins values compared to young animals (Group 1 and 2). With regards to albumin, the animals of Group 2 were lower than those of Group 3 and 4. Cholesterol was higher for Group 1 animals in relation to Group 2 and 4. Triglycerides and creatinine also presented variations between groups. The group of animals aged over 73 months presented higher triglyceride levels compared to animals in Goup 1 and 2. The lower triglyceride values were observed in Group 2 donkeys, although not statistically different from the values of the Group 1 and 4 . As for creatinine significantly lower values were observed in Group 1 animals in relation to Group 3, 4, and 5 which were similar. Only ALT and CK elements showed no significant differences between age groups assessed (Table 3). Animals in Group 2 had calcium values significantly lower than the other groups, which were similar. Phosphorus showed higher for the animals of Group 1 with a gradual decrease with advancing age of the animals. The Ca:P ratio was similar between Group 1, 2, 3, 4 and Group 5 higher than that of Group 1 and 2. The animals in Group 4 and 5 showed similar values for magnesium, however superior to the other age groups, with the lowest serum concentration observed in donkeys belonging to Group 1. Regarding AST enzyme, the animals of Group 1 showed lower values than the others. Alkaline phosphatase showed great variation between

Table 2. Mean values and standard deviations of proteins and metabolites of the Pêga breed, according to age groups

\begin{tabular}{|c|c|c|c|c|c|}
\hline $\begin{array}{l}\text { Biochemical } \\
\text { parameters }\end{array}$ & $\begin{array}{c}\text { Group 1 } \\
(\leq 6 \text { months }) \\
(n=15)\end{array}$ & $\begin{array}{c}\text { Group } 2 \\
(7-12 \text { months }) \\
(\mathrm{n}=28)\end{array}$ & $\begin{array}{c}\text { Group } 3 \\
(13-48 \text { months }) \\
(\mathrm{n}=31)\end{array}$ & $\begin{array}{c}\text { Group } 4 \\
(49-72 \text { months }) \\
(\mathrm{n}=19)\end{array}$ & $\begin{array}{c}\text { Group 5 } \\
(\geq 73 \text { months }) \\
(\mathrm{n}=30)\end{array}$ \\
\hline T. prot. (g/dL) & $7.40 \pm 1.45 c$ & $7.42 \pm 0.76 \mathrm{~b}, \mathrm{c}$ & $7.76 \pm 0.88 \mathrm{a}, \mathrm{b}, \mathrm{c}$ & $8.10 \pm 0.74 a$ & $7.94 \pm 0.84 a, b$ \\
\hline Alb. (g/dL) & $2.61 \pm 0.42 \mathrm{a}, \mathrm{b}$ & $2.32 \pm 0.75 b$ & $2.70 \pm 0.37 \mathrm{a}$ & $2.83 \pm 0.71 \mathrm{a}$ & $2.77 \pm 0.90 \mathrm{a}, \mathrm{b}$ \\
\hline Glob. (g/dL) & $4.79 \pm 1.54 \mathrm{a}$ & $5.20 \pm 0.92 \mathrm{a}$ & $5.09 \pm 0.95 \mathrm{a}$ & $5.46 \pm 0.78 \mathrm{a}$ & $5.15 \pm 0.93 a$ \\
\hline A:G ratio & $0.59 \pm 0.22 \mathrm{a}$ & $0.51 \pm 0.41 \mathrm{a}$ & $0.54 \pm 0.14 a$ & $0.54 \pm 0.18 \mathrm{a}$ & $0.59 \pm 0.40 \mathrm{a}$ \\
\hline Chol. (mg/dL) & $103.73 \pm 32.36 \mathrm{a}$ & $74.43 \pm 24.38 b$ & $83.42 \pm 29.74 a, b$ & $70.68 \pm 16.91 b$ & $77.07 \pm 10.15 a, b$ \\
\hline Trigl. (mg/dL) & $72.93 \pm 45.92 \mathrm{~b} . c$ & $70.9 \pm 38.60 c$ & $117.19 \pm 67.22 \mathrm{a}, \mathrm{b}$ & $130.31 \pm 90.17 \mathrm{a}, \mathrm{b}, \mathrm{c}$ & $143.57 \pm 83.93 a$ \\
\hline Uric.acid (mg/dL) & $2.17 \pm 1.33 \mathrm{a}$ & $1.73 \pm 1.46 \mathrm{a}$ & $1.62 \pm 1.10 \mathrm{a}$ & $1.39 \pm 0.56 \mathrm{a}$ & $2.10 \pm 1.74 \mathrm{a}$ \\
\hline Creat. (mg/dL) & $0.97 \pm 0.08 \mathrm{c}$ & $1.09 \pm 0.26 \mathrm{~b}, \mathrm{c}$ & $1.18 \pm 0.16 \mathrm{a}, \mathrm{b}$ & $1.28 \pm 0.27 a$ & $1.17 \pm 0.16 \mathrm{a}, \mathrm{b}$ \\
\hline Urea (mg/dL) & $31.55 \pm 10.25 \mathrm{a}$ & $34.13 \pm 5.59 \mathrm{a}$ & $30.94 \pm 5.27 \mathrm{a}$ & $27.61 \pm 7.39 a$ & $30.86 \pm 6.02 \mathrm{a}$ \\
\hline
\end{tabular}

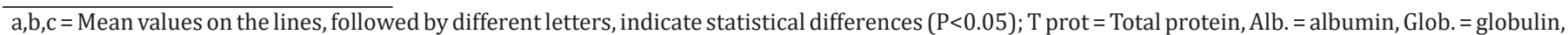
Chol. $=$ cholesterol, Trigl. $=$ triglycerides, Creat. $=$ creatinine.

Table 3. Mean values and standard deviations of the minerals and serum enzymes of Pêga breed donkeys according to age groups

\begin{tabular}{|c|c|c|c|c|c|}
\hline $\begin{array}{l}\text { Biochemical } \\
\text { parameters }\end{array}$ & $\begin{array}{c}\text { Group } 1 \\
(\leq 6 \text { months }) \\
(n=15)\end{array}$ & $\begin{array}{c}\text { Group } 2 \\
(7-12 \text { months }) \\
(\mathrm{n}=28)\end{array}$ & $\begin{array}{c}\text { Group } 3 \\
(13-48 \text { months }) \\
(\mathrm{n}=31) \\
\end{array}$ & $\begin{array}{c}\text { Group } 4 \\
\text { (49-72 months) } \\
(\mathrm{n}=19) \\
\end{array}$ & $\begin{array}{c}\text { Group } 5 \\
(\geq 73 \text { months }) \\
(n=30)\end{array}$ \\
\hline $\mathrm{Ca}(\mathrm{mg} / \mathrm{dL})$ & $13.46 \pm 0.88 \mathrm{a}$ & $12.48 \pm 1.25 b$ & $13.05 \pm 1.11 \mathrm{a}$ & $13.28 \pm 0.97 \mathrm{a}$ & $13.21 \pm 1.00 \mathrm{a}$ \\
\hline $\mathrm{P}(\mathrm{mg} / \mathrm{dL})$ & $6.37 \pm 1.15 \mathrm{a}$ & $4.09 \pm 0.86 b$ & $3.56 \pm 0.85 b, c$ & $3.07 \pm 1.15 \mathrm{c}, \mathrm{d}$ & $2.79 \pm 0.78 d$ \\
\hline Ca:P ratio & $2.16 \pm 0.44 \mathrm{~b}$ & $3.20 \pm 0.72 b$ & $3.94 \pm 1.31 \mathrm{a}, \mathrm{b}$ & $4.92 \pm 1.93 \mathrm{a}, \mathrm{b}$ & $5.20 \pm 1.97 a$ \\
\hline $\mathrm{Mg}(\mathrm{mg} / \mathrm{dL})$ & $2.53 \pm 0.29 c$ & $2.89 \pm 0.50 \mathrm{~b}$ & $2.88 \pm 0.59 b$ & $3.21 \pm 0.48 \mathrm{a}$ & $3.26 \pm 0.55 a$ \\
\hline ALT(U/L) & $9.47 \pm 3.94 \mathrm{a}$ & $10.18 \pm 5.77 \mathrm{a}$ & $13.93 \pm 13.26 \mathrm{a}$ & $11.10 \pm 5.54 \mathrm{a}$ & $10.63 \pm 5.48 \mathrm{a}$ \\
\hline AST(U/L) & $246.33 \pm 50.15 b$ & $331.71 \pm 69.12 \mathrm{a}$ & $377.32 \pm 75.81 \mathrm{a}$ & $370.32 \pm 93.24 \mathrm{a}$ & $375.30 \pm 86.05 a$ \\
\hline $\mathrm{ALP}(\mathrm{U} / \mathrm{L})$ & $354.67 \pm 105.04 \mathrm{a}$ & $248.97 \pm 53.20 \mathrm{a}, \mathrm{b}$ & $219.36 \pm 41.52 b, c$ & $169.53 \pm 34.75 \mathrm{~d}$ & $184.73 \pm 48.81 \mathrm{c}, \mathrm{d}$ \\
\hline GGT(U/L) & $78.40 \pm 17.79 \mathrm{a}$ & $65.46 \pm 26.68 \mathrm{~b}$ & $62.63 \pm 24.72 b$ & $49.63 \pm 23.01 c$ & $54.32 \pm 18.73 c$ \\
\hline $\mathrm{CK}(\mathrm{U} / \mathrm{L})$ & $342.47 \pm 345.24 \mathrm{a}$ & $236.48 \pm 168.20 \mathrm{a}$ & $371.33 \pm 246.83 a$ & $232.78 \pm 129.43 a$ & $259.32 \pm 117.95 a$ \\
\hline
\end{tabular}

$\mathrm{a}, \mathrm{b}, \mathrm{c}=$ Mean values on the lines followed by different letters, indicate statistical differences $(\mathrm{P}<0.05) ; \mathrm{Ca}=$ Calcium, $\mathrm{P}=$ phosphorus, Mg $=$ magnesium, $\mathrm{AL}=$ alanine, $\mathrm{ALT}=$ aminotransferase, $\mathrm{AST}=$ aspartate aminotransferase, $\mathrm{ALP}=$ alkaline phosphatase, $\mathrm{GGTY}=$ gamma glutamyl transferase, $\mathrm{CK}=\mathrm{creatine}$ kinase. 
Table 4. Mean values and standard deviations of the serum biochemical parameters of Pêga breed donkeys according to sex

\begin{tabular}{|c|c|c|c|}
\hline \multirow{2}{*}{ Biochemical parameters } & Females & Males & Females/Males (Mean) \\
\hline & $(n=94)$ & $(n=29)$ & $(\mathrm{n}=123)$ \\
\hline T.prot.(g/dL) & $7.83 \pm 0.97 \mathrm{a}$ & $7.41 \pm 0.72 b$ & $7.73 \pm 0.93$ \\
\hline Alb. (g/dL) & $2.60 \pm 0.67 \mathrm{a}$ & $2.77 \pm 0.77 \mathrm{a}$ & $2.64 \pm 0.69$ \\
\hline Glob. (g/dL) & $5.27 \pm 0.99 a$ & $4.64 \pm 0.90 \mathrm{~b}$ & $5.12 \pm 1.00$ \\
\hline A:G ratio & $0.52 \pm 0.25 b$ & $0.65 \pm 0.41 \mathrm{a}$ & $0.55 \pm 0.30$ \\
\hline Chol. (mg/dL) & $81.81 \pm 27.41 \mathrm{a}$ & $74.59 \pm 14.93 a$ & $80.11 \pm 25.17$ \\
\hline Trigl. (mg/dL) & $122.55 \pm 78.07 \mathrm{a}$ & $68.17 \pm 32.75 b$ & $109.73 \pm 73.69$ \\
\hline Creat. (mg/dL) & $1.15 \pm 0.21 \mathrm{a}$ & $1.12 \pm 0.23 \mathrm{a}$ & $1.15 \pm 0.22$ \\
\hline Ureia(mg/dL) & $30.86 \pm 6.93 a$ & $32.32 \pm 6.42 \mathrm{a}$ & $31.21 \pm 6.82$ \\
\hline $\operatorname{Uric} \operatorname{acid}(\mathrm{mg} / \mathrm{dL})$ & $1.73 \pm 1.29 \mathrm{a}$ & $2.00 \pm 1.19 \mathrm{a}$ & $1.79 \pm 1.34$ \\
\hline $\mathrm{Ca}(\mathrm{mg} / \mathrm{dL})$ & $12.86 \pm 1.09 \mathrm{~b}$ & $13.63 \pm 0.98 \mathrm{a}$ & $13.04 \pm 1.10$ \\
\hline $\mathrm{P}(\mathrm{mg} / \mathrm{dL})$ & $3.60 \pm 1.35 b$ & $4.27 \pm 1.53 \mathrm{a}$ & $3.76 \pm 1.42$ \\
\hline Ca:P ratio & $4.09 \pm 1.67 \mathrm{a}$ & $3.75 \pm 2.00 \mathrm{a}$ & $4.01 \pm 1.75$ \\
\hline Mag. (mg/dL) & $3.04 \pm 0.59 \mathrm{a}$ & $2.81 \pm 0.41 \mathrm{a}$ & $2.98 \pm 0.56$ \\
\hline ALT(U/L) & $11.37 \pm 8.96 \mathrm{a}$ & $11.03 \pm 4.82 \mathrm{a}$ & $11.29 \pm 8.16$ \\
\hline AST(U/L) & $352.16 \pm 83.08 \mathrm{a}$ & $340.41 \pm 100.64 a$ & $349.39 \pm 87.24$ \\
\hline ALP(U/L) & $220.68 \pm 70.45 a$ & $245.18 \pm 99.04 a$ & $226.46 \pm 78.38$ \\
\hline GGT(U/L) & $52.93 \pm 27.11 \mathrm{a}$ & $71.30 \pm 24.18 \mathrm{a}$ & $62.11 \pm 24.06$ \\
\hline $\mathrm{CK}(\mathrm{U} / \mathrm{L})$ & $272.54 \pm 173.79 b$ & $426.67 \pm 254.57 a$ & $308.88 \pm 208.34$ \\
\hline
\end{tabular}

$\mathrm{a}, \mathrm{b}=$ Mean values on the lines followed by different letters, indicate statistical difference $(\mathrm{P}<0.05)$; T prot $=$ Total protein, Alb. $=$ albumin, Glob. $=$ globulin, Chol $=$ cholesterol Trigl $=$ triglycerides, Creat. $=$ creatinine, $\mathrm{Ca}=$ calcium, $\mathrm{P}=$ phosphorus, $\mathrm{Mg}=$ magnesium, $\mathrm{ALT}=$ alanine aminotransferase, $\mathrm{AST}=$ aspartate aminotransferase, $\mathrm{ALP}=$ alkaline phosphatase, $\mathrm{GGT}=$ gamma glutamyl transferase, $\mathrm{CK}=$ creatine kinase .

the groups, and the animals from Group 1 and 2 showed the highest values, decreasing with advancing age. GGT values were higher in Group 1, with decreasing variation of the younger to older animals.

The results of the comparison between the sexes are shown in Table 4. It is noted in Table 4 that the females showed higher values than males in relation to total proteins, globulins and triglycerides, while males showed higher values for the ratio A:G, calcium, phosphorus and CK. Other elements evaluated were similar between males and females.

\section{DISCUSSION}

The results of this study for elements such as globulins, uric acid and urea, agree with other studies that found no significant differences in the serum levels of these elements between age groups (Orlandi et al. 1997, Jordana et al. 1998, Alves 2008, Etana et al. 2011, Girardi et al. 2013, Stanisic et al. 2015). However, studies by Caldin et al. (2005), to asses the Ragusana breed, in Italy, had lower values for urea element in young animals. As reported by Laus et al. (2015), studying donkeys of mixed breeds of Italy, animal's subjects of this study found no significant differences between sexes for such elements as albumin, cholesterol, creatinine, urea, cholesterol, ALT, AST and ALP. Urea concentrations similar for males and females in this study differ from Alves findings (2008) reporting higher values in males. Alves (2008), studying donkeys of the Brazilian breed, reports higher values for the ratio $A: G$ in younger animals. In contrast, studies by Alberghina et al. (2013), on donkeys of the Ragusana breed, as well as the results presented in this work, found no significant differences in animals of different ages. The higher serum concentrations of total protein observed in animals of 49-72 months of age
(Group 4) in this study is consistent with Alves (2008) reporting total protein values in donkeys older than 18 months as being the highest. However, in studies by Alberghina et al. (2013), animals aged over 12 months showed the highest values of total protein, and Caldin et al. (2005) protein levels did not differ between the age groups. The rates reported in the work of Mori et al. (2003) suggested as a reference for the donkeys of the Brazilian breed, have lower values than those found in this study, for total proteins. We suggest that the largest value in total protein concentrations is in the animals of Group 4 and 5 in relation to Group 1, related to an increase, although not statistically significant in globulins values due to increased immunocompetence in the presence of environmental challenges encountered and periodic vaccinations.

The highest total protein value found in females corroborates Girardi et al. (2013) when reporting the value of this element being higher in females. We attribute the higher concentration of total protein serum and globulins in females of this study to the physiological responses of females in puerperium and lactation, since 15 jennies (female donkeys) were lactating. However, there are previous studies in which total protein values were higher in males (Gacek et al. 1973, Mori et al. 2003, Pitel et al. 2006). Studies by Cavalcante et al. (2012), and Laus et al. (2015) report no significant difference between sex for total protein.

The significant difference with lowest value observed for albumin in the donkey 2 group, are opposed to the findings of other researchers in stating no significant difference as to the albumin levels, in the face of different age groups (Girardi et al. 2013, Sgorbini et al. 2013, Stanisic et al. 2015).

Given the reference values reported by Mori et al. (2003), in general, the results for the donkeys of the Pega breed 
evaluated in this work, as to albumin, were slightly lower. This is contrary to the results of studies by Mori et al. (2003), Pitel et al. (2006), Girardi et al. (2013) pointing to albumin levels higher in males. Serum concentrations of albumin in the animals of this study were similar for males and females. The lowest value observed for albumin in Group 2 is probably due to a reduction in food intake due to stress after weaning.

For cholesterol, the average values for the animals in this study are lower than those found by Mori et al. (2003). But are in line with the findings of Girardi et al. (2013), who studied donkeys of the Pega breed and also found higher cholesterol levels in younger animals. Whereas Chiofalo et al. (2012), studying animals of the Pantelleria breed, found no significant differences between the age for the cholesterol element. The highest concentration of cholesterol in Group 1 donkeys in relation to Group 2 must be linked to the animals' diet, which in this age group (up to 6 months) is predominantly based on milk and also the intense metabolic activity at this stage of accelerated body growth. According to Carlson (1994), an increase in cholesterol concentrations is common in infant animals. Unlike the results of Girardi et al (2013) who found values for the higher cholesterol in males, in this study the metabolite values were similar for males and females.

The results for triglycerides are similar to those from the studies by Jordana et al. (1998), Alves (2008), and Girardi et al. (2013), who also found higher valuesin older animals. As stated by Watson et al. (1990), serum triglyceride levels in donkeys tend to increase with increasing body weight. However, a recent study (Stanisic et al. 2015) with donkeys from the Balkans, no significant difference between different age groups for this element was reported. When analyzing gender differences, the finding of higher triglyceride values in females in this study contradicts the findings of Laus et al. (2015) who found similar values for males and females. The higher serum triglycerides concentration found for females in this study should be due to a mobilization of fat reserves for energy supply during lactation.

The results for creatinine are similar to those found by Girardi et al. (2013), who also working with Pêga breed animals found average values lower than those presented by Mori et al. (2003), for donkeys of the Brazilian breed. Caldin et al. (2005), Pitel et al. (2006) and Alves (2008) reported values higher than those found for creatinine in this study, when analyzing young animals. The lower creatinine values in animals with up to 6 months of age is due to the lower volume of muscle mass in relation to animals over 12 months of age. Evans (2009) says that creatinine values are dependent on the muscle mass of the animal, so it is expected that the young donkeys, show lower serum creatinine levels. Literature shows serum creatinine values differ between males and females, and in some studies (Pitel et al. 2006, Etana et al. 2011, Girardi et al. 2013, Orlandi et al. 2013), the values are higher for males and in another (Mori et al. 2003), for females. Contrary to the above studies, the Pêga breed donkeys in the present study showed similar values of this metabolite for males and females.

The lowest value observed for calcium in Group 2, aged between 7 and 12 months, consist with Girardi et al. (2013) who observed serum calcium concentrations statistically lower in the donkeys of the Pêga breed with up to 1 year of age. This diverges from studies by Caldin et al. (2005), Sgorbini et al.
(2013) and Stanisic et al. (2015) who found no significant differences for this element in relation to age. This lower serum concentration of calcium in the animal 7 to 12 months may be due to a reduction in the mineral intake in the diet and the high demand during the active bone growth rate, since these animals were post weaning period, a period responsible for severe stress in animals, which leads to a reduction in food intake. Previous studies have reported the finding of serum calcium concentrations higher in females (Mori et al. 2003, Pitel et al. 2006, Girardi et al. 2013). However, in this study significantly higher values were observed in males.

The values found for phosphorus confirm results of previous studies in which young animals showed higher values than the other age groups (Jordana et al. 1998, Caldin et al. 2005, Alves 2008, Girardi et al. 2013). However, Ahmed et al. (2007) studied Egyptian donkeys and Stanisic et al. (2015) found no significant difference for this element between the age groups. The increase observed in the concentration of $\mathrm{P}$ in the donkey with up to 6 months of age (Group 1) with a gradual decrease with increasing age may be a result of the anabolic action of growth hormone $(\mathrm{GH})$ and the higher amount of this element in the diet, since during this phase of life, the donkeys have a diet consisting largely of breast milk, which has a Ca:P ratio of 1: 1. Generally, phosphorus plasma levels reflect an increase in periods of rapid bone growth, which occurs in young animals, and gradually suffers decline with advancing age Evans (2009). Regarding gender, the highest phosphorus concentration observed in male donkeys in this study is consistent with Girardi et al. (2013) and Orlandi et al. (2013) who also reported phosphorus values as being higher for males. In contrast, Ahmed et al. (2007) found no difference between sexes for phosphorus. The presence of lower concentrations of $\mathrm{Ca}$ and $\mathrm{P}$ in females of this study should be attributed to a high demand of these elements in pregnant and lactating females.

The lower value of the Ca:P ratio observed in Group 1 and 2 compared to Group 5 may result in serum $P$ behavior, which showed higher values in young animals compared to older ones. Alves (2008) studying donkeys of the Brazilian breed, points to higher values for the Ca:P ratio in animals over 18 months. The similarity of the values observed for the Ca:P ratio for males and females contradicts the findings of Orlandi et al. (2013) who found higher values for this ratio in males.

Unlike the findings of Caldin et al. (2005) and Girardi et al. (2013), which found no significant differences between age groups for serum magnesium, in this study there was a lower value for electrolyte in animals with up to 6 months of age, followed by a gradual increase with advancing age. In contrast, Alves (2008), says that the values for magnesium varied greatly between the ages, the highest value found in younger animals. As in this study, Ahmed et al. (2007) found no significant differences between the sexes, while Alves (2008) and Girardi et al. (2013) reported higher values for males. The differences in magnesium values regarding age groups can be attributed to the diet of the animals, which in the young phase consists largely of breast milk, which has a lower concentration of this mineral in relation to grasses and legumes.

The lower values for AST in donkeys from Group 1 corroborate previous studies that claimed the serum levels of this enzyme to be lower in younger animals (Alves 2008, Etana et al. 2011, 
Girardi et al. 2013). In contrast, Stanisic et al. (2015) reported a higher value for AST in animals with up to 3 years of age. Lower values of AST were attributed to donkeys up to six months old, with less muscle mass and reduced physical activity common to animals in this age group. Regarding the influence of gender on serum concentrations of this enzyme, there are discrepancies in literature. Orlandi et al. (2013) found higher values for males, Girardi et al. (2013) for females and in this study there were no significant differences between sexes.

ALP activity showed great variation between age groups in this study, being significantly higher in younger donkeys up to 12 months of age, followed by gradual decrease with increasing age, corroborating the results obtained in previous studies (Caldin et al. 2005, Etana et al. 2011, Girardi et al. 2013, Laus et al. 2015, Stanisic et al. 2015). Not befitting Girardi et al (2013), who reported higher values for males. Higher values for the ALP in young animals and a decrease with increasing age is a known fact, with the high observed values being attributed to high osteoblastic activity during intense growth phase (Muñoz et al. 2012). According to literature, ALP values decrease with the evolving of age and with the closing of the bony epiphysis (Bauer et al. 1989, Brommer et al. 2001).

A higher value observed for serum GGT in donkeys up to six months and a significant decrease with advancing age, corroborates Alves (2008), who found significantly higher values for this enzyme in the donkeys of the Brazilian breed with up to six months of age. However, studies by Caldin et al. (2005) found no significant differences between ages for this element, while Girardi et al. (2013) and Stanisic et al. (2015) found higher values for the enzyme in animals over 1 year. This is postulated to be the highest concentration of enzyme in animals of up to 6 months of age resulting in greater absorption of the enzyme by colostrum and breast milk. Checking the influence of gender on the concentration of GGT, the similarity of values for males and females matches that of Laus et al. (2015) who found no significant differences between sexes for the enzyme, however this differs from Alves (2008) who found greater enzyme values in male donkeys of the Brazilian breed.

Although CK enzyme values of the present study was similar between age groups, corroborating the results found by other researchers (Girardi et al. 2013, Stanisic et al. 2015), males presented significantly higher values than the values for females for this enzyme. In contrast, Laus et al. (2015), studying donkeys of mixed breeds from Italy, showed significant differences for CK, with higher values in young animals. However, Alves (2008) and Laus et al. (2015) found no significant differences between males and females. The highest values of the enzyme observed in male donkeys can be attributed to increased muscle mass of animals in relation to females.

Analyzing concurrently the results found in this study and the data in literature for the biochemical profile of donkeys, it is possible to notice several differences between the reported values. In reviews laboratory techniques are used with different accuracies, as well as different temperatures, instruments and reagents (Mori et al. 2003), which could lead to these differences. Factors such as breed, management and delimitations of age also influence the values for biochemical profiles. The importance of standardization of different ages for studies involving biochemical profile analysis in different age groups is highlighted.

\section{CONCLUSION}

Based on the results of this study with Pêga breed donkeys and comparisons with other studies in various asinine breeds, it is found that age and sex influence serum biochemistry values of various elements. It is essential to consider these factors when establishing biochemical standards to be used as references.

Ethics and biosafety committee.- This study was approved by Ethics Committee on Animal Use of the Federal University of Uberlandia (CEUA/UFU), under Protocol no.160/13.

\section{REFERENCES}

Ahmed A.E., Abdel-Hamid H., Abdel-Rahim A.A. \& Ismail M.N. 2007. The influence of age and sex on some blood parameters inhealthy donkey in south Valley Egypt. Beni-Suef Vet. Med. J. 5:151-158.

Alberghina D., Fazio A., Arfuso F., Sciano S., Zumbo A. \& Piccione G. 2013. Reference intervals of serum protein concentrations from clinically healthy female Ragusana donkeys (Equus asinus) determined by cellulose acetate electrophoresis. J. Equine Vet. Sci. 33(6):433-436. http://dx.doi. org/10.1016/j.jevs.2012.07.012.

AL-Busadah K.A. \& Homeida A.M. 2005. Some physical variables, biochemical and hematological parameters in Hassawi Ass. Scient. J. King Faisal Univ. 6:145-152.

Alves L.M.D. 2008. Influência da idade e do sexo sobre o perfil bioquímico sérico de jumentos da raça Brasileira. Dissertação de Mestrado em Genética e Bioquímica, Universidade Federal de Uberlândia, Uberlândia. 38p.

Araújo N.A. 2010. Origem Histórica do Jumento Doméstico. Grafipress, Patos de Minas, MG. 320p

Bauer J.E., Asquith R.L. \& Kivipelto J. 1989. Serum biochemical indicators of liver function in neonatal foals. Am. J. Vet. Res. 50(12):2037-2041. PMid:2610429.

Brommer H., van Oldruitenborgh-Oosterbaan M.M.S. \& Kessels B. 2001. Haematological and blood biochemical characteristics of Dutch Wamblood foals managed under three different rearing conditions from birth to 5 months of age. Vet. Quarterly 23(2):92-95. http://dx.doi.org/10.1080/0 1652176.2001.9695090. PMid:11361107.

Caldin M., Furlanello T., Solano-Gallego L., Lorenzi D.D., Carli E., Tasca S. \& Lubas G. 2005. Reference ranges for haematology, biochemical profile and electrophoresis in a single herd of Ragusana donkeys from Sicily (Italy). Comp. Clin. Pathol.14(1):5-12. http://dx.doi.org/10.1007/s00580-005-0544-8.

Carlson G.P. 1994. Testes de química clínica, p.395-423. In: Smith B. (Ed.), Tratado de Medicina Interna de Grandes Animais. Vol.1. Manole, São Paulo.

Carroccio A., Cavataio F., Montalto G., D’Amico D., Alabrese L. \& Iacono G. 2000. Intolerance to hydrolyzed cow's milk proteins in infants: clinical characteristic and dietary treatment. Clin. Exp. Allergy 30(11):597-603. http://dx.doi.org/10.1046/j.1365-2222.2000.00925.x. PMid:11069569.

Cavalcante P.H., Silva A.C.C., Sakamoto S.M. \& Soto Blanco B. 2012. Serum protein fractions in Brazilian breed donkeys using agarose gel electrophoresis. Turk. J. Vet. Anim. Sci., Ankara, 36:9-12.

Chiofalo R., Liotta L., Sanzarello L. \& Chiofalo V. 2012. Nutritional status of the endangered Pantelleria donkey breeds. European Federation Anim. Sci. 129:161-164.

Duncan J.R., Prasse K.W. \& Mahaffey E.A. 1994. Veterinary Laboratory Medicine Clinical Pathology. University Press, Ames, Iowa, p.118-122. 
Etana K.M., Jenbere T.S., Bojia E. \& Negussie H. 2011. Determination of reference hematological and serum-biochemical values for working donkeys of Ethiopia. Vet. Res. 4:90-94.

Evans G.0. 2009. Animal Clinical Chesmistry: a pratical guide for toxicologists and biomedical researchers. 2nd ed. CRC Press, Boca Raton. 310p. http:// dx.doi.org/10.1201/9781420080124.

Gacek F., Bizutti O., Perdigão de Oliveira F.R.A. \& Leão J.F.S. 1973. Eletroferograma das proteínas séricas de jumentos Equus asinus L. normais da raça Brasileira. Bolm Indústr. Anim. 30:161-171.

Girardi A.M., Marques L.C., Toledo C.Z.P., Barbosa J.C., Maldonado W., Jorge R.L.N. \& Nogueira C.A.S. 2013. Biochemical profile of the Pêga donkey (Equus asniuns) breed: influence of age and sex. Comp. Clin. Pathol. 23(4):941-947. http://dx.doi.org/10.1007/s00580-013-1718-4.

IBGE 2014. Produção da Pecuária Municipal (PPM). Instituto Brasileiro de Geografia e Estatística.

Jordana J., Folch P. \& Cuenca R. 1998. Clinical biochemical parameters of the endangered Catalonian donkey breed: normal values and the influence of sex, age, and management practices effect. Res. Vet. Sci. 64(1):7-10. http:// dx.doi.org/10.1016/S0034-5288(98)90107-2. PMid:9557798.

Kugler W., Grunenfelder H.P. \& Broxham E. 2008. Donkey breeds in Europa. Monitoring Institute for Rare Breeds and Seeds in Europe, St Gallen, Switzerland. 62p.

Laus F., Spaterna A., Faillace V., Paggi E., Serri E., Vullo C., Cerquetella M. \& Tesei B. 2015. Reference values for hematological and biochemical parameters of mixed breed donkeys (Equus asinus). Wulfenia J., Klagenfurt, 22:294-304.

Mori E., Fernandes W.R., Mirandola R.M.S., Kubo G., Ferreira R.R., Oliveira J.V. \& Gacek F. 2003. Reference values on serum biochemical parameters of Brazilizan donkey (Equus asinus) breed. J. Equine Vet. Sci. 23(8):358-364. http://dx.doi.org/10.1016/S0737-0806(03)01025-6.

Muñoz A., Riber C., Trigo P. \& Castejón F. 2012. Age and gender related variations in hematology, clinical biochemistry, and hormones in Spanish fillies and colts. Res. Vet. Sci. 93(2):943-949. http://dx.doi.org/10.1016/j. rvsc.2011.11.009. PMid:22230595.
Orlandi M., Leotta R., Berni P. \& Curadi M.C. 1997. Metabolic profile in the Amiatan donkey (Tuscany). Annali della Facolta' di Medicina Veterinaria di Pisa 50:47-53.

Orlandi M., Curadi M.C., Giogertti A. \& Benedetti R. 2013. Caratterizzazione morfo-funzionale e fisiológica dell'asino amiatino. Ippologia 24:11-16.

Pitel P., Moulin M., Valette J.P., Dumontier S., Petit L. \& Fortier G. 2006. CoroucéMalblanc A. Approchedes valeurs hématologiques et bioquimiques chez deux races asines. Pratique Vétérinaire Équine 38:19-25.

Sgorbini M., Bonelli F., Rota A., Baragli P., Marchetti V. \& Corazza M. 2013. Hematology and clinical chemistry in Amiata donkey foals from birth to 2 months of Age. J. Equine Vet. Sci. 33(1):35-39. http://dx.doi.org/10.1016/j. jevs.2012.04.010.

Stanisic L., Dimitrijevic V., Simeunovic P., Lakic N., Radovic I., Ivankovic A., Stevanovic J. \& Stanimirovic Z. 2015. Morphological, biochemical and hematological characterization of endangered Balkan donkey breed. Acta Vet. 65(1):125-136. http://dx.doi.org/10.1515/acve-2015-0010.

Starkey P. \& Starkey M. 2000. Regional and world trends in donkey populations. A resource book of the Animal Traction Network for eastern and Southern Africa (ATNESA), p.10-21. In: Starkey P. \& Fielding D. (Eds), Donkeys, People and Development. ACP-EU Technical Centre for Agricultural and Rural Cooperation (CTA), Wageningen.

Tasker J.B. 1978. Reference values for clinical chemistry using the Coulter Chemistry System. Cornell Vet. 68(4):460-479. PMid:710143.

Trachsel D., Brehm W. \& Tschudi P. 2005. Reference values for haematology and clinical chemistry in donkeys. Tierärztl. Praxis Großtiere 1:55-60.

Veronesi M.C., Gloria A., Panzani S., Sfirro M.P., Carluccio A. \& Contri A. 2014 Blood analysis in newborn donkeys: hematology, biochemistry, and blood gases analysis. Theriogenology 82(2):294-303. http://dx.doi.org/10.1016/j. theriogenology.2014.04.004. PMid:24831574.

Watson T.D., Packard C.J., Shepherd J. \& Fowler J.N. 1990. An investigation of relationship between body condition and plasma lipid and liprotein concentration on 24 donkeys. Vet. Rec. 127(20):498-500. PMid:2275089.

Zinkl J.G., Mae D., Guzman Merida P., Farver T.B. \& Humble J.A. 1990. Reference ranges and the influence of age and sex on hematologic and serum biochemical values in donkeys (Equus asinus). Am. J. Vet. Res. 51(3):40. PMid:2316919. 